\title{
Budgeting Practices: Its Impact on the Profitability of Small and Medium Enterprises in Isabela
}

\author{
Christian Philip A. Fortuna \\ College of Business and Management, Isabela State University, Cauayan Campus, Cauayan City, Isabela, 3305, Philippines
}

Received December 28, 2020; Revised March 9, 2021; Accepted March 29, 2021

\section{Cite This Paper in the following Citation Styles}

(a): [1] Christian Philip A. Fortuna, "Budgeting Practices: Its Impact on the Profitability of Small and Medium Enterprises in Isabela," Universal Journal of Accounting and Finance, Vol. 9, No. 3, pp. 336 - 346, 2021. DOI: 10.13189/ujaf.2021.090307.

(b): Christian Philip A. Fortuna (2021). Budgeting Practices: Its Impact on the Profitability of Small and Medium Enterprises in Isabela. Universal Journal of Accounting and Finance, 9(3), 336 - 346. DOI: 10.13189/ujaf.2021.090307.

Copyright $@ 2021$ by authors, all rights reserved. Authors agree that this article remains permanently open access under the terms of the Creative Commons Attribution License 4.0 International License

\begin{abstract}
A budget is an economic tool for realizing and facilitating the vision of an organization. If a budget is to serve as a useful tool, then it is essential that all phases of budgeting are appropriately linked and managed [1]. This study made use of the three types of research by methods: descriptive research to gather the profile of respondents (size and type of business), budgeting practices (manager's participation, linking budget development to strategy, rational allocation of resources, flexibility continuous budget, and reduction of complexity and use of information technology) and level of profitability; causal-comparative research to determine differences between variables; and correlational research to determine the degree of relationship between variables and for hypothesis testing. Primarily, the 331 respondents of the study were from the four-commercial centers in Isabela, broken down as follows, Cauayan City (116), Ilagan City (58), Santiago City (121) and Municipality of Roxas (36). Results of the study showed that test of difference in respondents' budgeting practices regarding managers participation, reduction of complexity and use of information technology significantly differed between small and medium enterprises. Additionally, when the respondents were grouped according to the type of business, merchandising and servicing business varies with manufacturing business budgeting practices regarding managers participation and linking budget development to strategy. Conversely, small-sized and medium-sized businesses significantly differ as regards their level of profitability. Furthermore, the test of the relationship on respondents' perception of budgeting practices is used and their level of profitability
\end{abstract}

reveals a direct and significant relationship.

Keywords Budgeting Practices, Profitability, Small and Medium Enterprises, Causal-Comparative, Correlation, Regression

\section{Introduction}

Finance is the lifeblood of a business. Consequently, financial planning is considered of great importance to a businessman [2,3]. Financial planning encompasses not only the raising of funds, but it also covers the effective utilization of such funds [4,5]. A budget is an essential instrument for business organizations to have effective financial planning and control [6]. Hence, a budget is a systematic allocation of resources to realize the company's goals [7].

Budgeting encompasses the establishment of predetermined goals, the reporting of the actual result of performance and assessment of performance in terms of the predetermined objectives [8,9]. Nonetheless, budgeting can be susceptible to challenges which may deter effective attainment of the company's goals. Conclusively, it can either have a positive or negative impact on the financial performance of companies [10]. But, still this rests on how the operations are being managed effectively by the companies to attain their set targets. Hence, organizations should put in place or adopt budgeting practices which assist in accomplishing a 
principle and element of the budget process. Good integration of the budget process with other activities, such as planning and management functions, provides better financial and program decisions that lead to improving operations [11]. Prior studies concluded that there exists a positive relationship between budgeting practices and financial performance regarding return on asset [12]; growth in sales and profit [13].

The studies mentioned above had shown a relationship between budgeting practices and financial performance in which this present study tries to confirm or refute. The researcher conducted this study to reveal the current condition of SME's budgeting practices and level of profitability, as well as the relationship between the variables. Furthermore, little research into the budgeting practices used by SMEs as the variable possibly affecting their profitability has been conducted in the Philippine context. Thus, a further research priority for studying the relationship between the budgeting practices used and level of profitability of SMEs within the Philippines is warranted. Moreover, other variables (such as ROI, ROE and EVA) as a measure of profitability is included.

\subsection{Objectives of the Study}

This study aimed to analyze the budgeting practices used as perceived by the respondents in Isabela and its impact on the level of profitability of the businesses. Specifically, this research aimed to (1) determine the profile of the respondents in terms of size and type of the business; (2) determine the budgeting practices used as perceived by the respondents in terms of managers participation, linking budget development to strategy, rational allocation of resources, flexibility continuous improvement, reduction of complexity and use of information technology; (3) determine the level of profitability of the business enterprise; (4) analyze the difference between the budgeting practices used and level of profitability of the respondents when grouped according to their profile; and (5) analyze the relationship between the budgeting practices used and level of profitability of the respondents.

\subsection{Conceptual Framework}

The paradigm presents the conceptual framework of the study. This includes the profile of the respondents: size and type of the business; budgeting practices used as perceived by the respondents in terms of managers participation, linking budget development to strategy, rational allocation of resources, flexibility continuous improvement, reduction of complexity and use of information technology; and level of profitability of the business enterprise. The one-headed arrow indicates the comparison between the budgeting practices used and level of profitability when grouped according to the respondents' profile. Furthermore, the two-way arrow indicates the relationship between the budgeting practices used and the level of profitability of the respondents.

\begin{tabular}{|c|c|c|}
\hline \multicolumn{3}{|c|}{$\begin{array}{l}\text { Profile of the Respondents } \\
\text { 1. Size of the business } \\
\text { 2. Type of the business }\end{array}$} \\
\hline $\begin{array}{l}\text { Budgeting Practices } \\
\text { 1. Manager's } \\
\text { Participation } \\
\text { 2. Linking budget } \\
\text { development to strategy } \\
\text { 3. Rational Allocation of } \\
\text { Resources } \\
\text { 4. Flexibility Continuous } \\
\text { Improvement } \\
\text { 5. Reduction of } \\
\text { Complexity and Use of } \\
\text { Information Technology }\end{array}$ & $\langle>$ & $\begin{array}{l}\text { Level of Profitability } \\
\text { 1. Growth in } \\
\text { Sales/Revenues } \\
\text { 2. Profit Margin } \\
\text { 3. Return on Investment } \\
\text { (ROI) } \\
\text { 4. Return on Assets } \\
\text { (ROA) } \\
\text { 5. Return on Equity } \\
\text { (ROE) } \\
6 . \text { Economic Value Added } \\
\text { (EVA) }\end{array}$ \\
\hline
\end{tabular}

Figure 1. The Research Paradigm

\section{Methodology}

\subsection{Research Design}

This study made use of the three types of research by methods: descriptive research to gather the profile of respondents, budgeting practices and level of profitability; causal-comparative research to determine differences between variables; and correlational study to determine the degree of relationship between variables and for hypothesis testing.

\subsection{Respondents of the Study}

Purposive sampling was used in the study. Primarily, the 331 respondents of the study were from the four-commercial centers in Isabela, broken down as follows Cauayan City (116), Ilagan City (58), Santiago City (121) and Municipality of Roxas (36). The Department of Trade and Industry (DTI) provided the list of small and medium businesses in Isabela.

Table 1. Respondents of the Study

\begin{tabular}{|c|c|c|}
\hline Commercial Centers & Population & Sample \\
\hline Cauayan City & 149 & 116 \\
\hline Ilagan City & 41 & 58 \\
\hline Santiago City & 151 & 121 \\
\hline Municipality of Roxas & 46 & 36 \\
\hline Total & 387 & 331 \\
\hline
\end{tabular}

The chosen respondents were the most appropriate 
since they were the most progressive regarding income classification in Isabela [14]. Additionally, the respondents of the study, Small and Medium Enterprises, were represented by the staff/officers within the company who was in charge of the budgeting function or part of the budgeting committee of the SMEs operating in the fourcommercial centers of Isabela.

\subsection{Research Instrument}

The researcher utilized the questionnaire as the primary source of the data gathering instrument. The questionnaire consisted of three parts: the first part dealt with the respondent's profile. The second part is the budgeting practice employed by SMEs, and lastly, level of profitability.

Company profile, the first part of the questionnaires implores information about the respondents' background. These variables are size and type of business. The second part was adopted questionnaire regarding budgeting practices which was developed by Mbothu [15]. The adopted questionnaire was revised being SMEs as the subject matter. For the reliability test of the adopted questionnaire, the Cronbach's Alpha was used. The reliability coefficient (alpha) was 0.925 . This high internal consistency suggests that the 24-item test is an internally consistent measure of budgeting practices. Lastly, the level of profitability which was measured regarding growth in sales/revenue, profit margin, return on investment (ROI), return on assets (ROA), return on equity (ROE) and economic value added (EVA).

Furthermore, the questionnaire was floated starting in January 2019 and was retrieved until April 2019. The respondents assessed the level of profitability by analyzing the company's financial statements (statement of financial position and statement of comprehensive income). Financial statement analysis is an important tool that assessed the company's specific areas of improvement and overall performance. The respondents conducted financial statement analysis to determine the level of profitability which was measured regarding growth in sales/revenue, profit margin, return on investment (ROI), return on assets (ROA), return on equity (ROE) and economic value added (EVA).

\subsection{Data Gathering Procedure}

The following procedures were conducted by the researcher to gather relevant information about the companies' profile, budgeting practices and level of profitability. First, a letter of request for the conduct of the study was prepared by the researcher. Then, the researcher floated the questionnaires and retrieved them from the respondents. After retrieving the questionnaires, the researcher tabulated and analyzed the data gathered from the respondents. Lastly, the researcher made a summary, presented and interpreted the data.

\subsection{Data Analysis}

Different statistical tools were used to treat the data which were tallied, tabulated and analyzed. These are frequency and tally percent which were used to describe the company profile, budgeting practices used and the level of profitability of the respondents; arithmetic mean which was used to determine the budgeting practices used as perceived by the respondents and their level of profitability. To evaluate the mean values of responses of the respondents, the Likert Scale of the numerical score was used, as shown below:

Table 2. Likert Scale for the Perception on Budgeting Practices and Level of Profitability

\begin{tabular}{|c|c|c|c|}
\hline \multirow{2}{*}{ Scale } & \multirow{2}{*}{ Range } & \multicolumn{2}{|c|}{ Qualitative Description } \\
\cline { 3 - 4 } & & $\begin{array}{c}\text { Perception on } \\
\text { Budgeting Practices }\end{array}$ & $\begin{array}{c}\text { Level of } \\
\text { Profitability }\end{array}$ \\
\hline 5 & $4.50-5.00$ & Strongly Agree & Very High \\
\hline 4 & $3.50-4.49$ & Agree & High \\
\hline 3 & $2.50-3.49$ & Moderately Agree & Average \\
\hline 2 & $1.50-2.49$ & Disagree & Low \\
\hline 1 & $1.00-1.49$ & Strongly Disagree & Very Low \\
\hline
\end{tabular}

T-test which was used to determine the difference in budgeting practices used and the level of profitability of the respondents when grouped according to the size of the business; Analysis of Variance (ANOVA) which was used to determine the difference in budgeting practices used and the level of profitability of the respondents when grouped according to the type of the business; and Pearson Correlation was used to determine the relationship between the budgeting practices used and the level of profitability of the respondents. Regression Analysis was used to determine if budgeting practices are a predictor of the respondents' level of profitability. Finally, the gathered data were processed using the Statistical Package for Social Sciences (SPSS).

\section{Results and Discussions}

\subsection{Profile of Small and Medium Enterprises, Isabela}

Table 3 shows the company profile of the respondents regarding the size and type of business.

Size of the Business. Regarding the size of the business, most of the respondents were small-sized enterprises (207 or $62.54 \%$ out of 331 ). In comparison, 124 or $37.46 \%$ were medium-sized enterprises. The result implies that small-sized enterprises dominate the industry.

As per record of Philippine Statistics Authority [16] of the 2016 List of Establishments, there are a total of 915,726 business operating in the Philippines, of which 
$9.50 \%(86,955)$ were small enterprises, and $0.44 \%(4,018)$ were medium enterprises.

Type of the Business. With regards to the type of business, most of the respondents were merchandising business (171 or $51.66 \%$ out of 331 respondents). While 120 or $36.25 \%$ were servicing business, and 40 or $12.09 \%$ are manufacturing business. The result implies that the merchandising and servicing business dominates the industry.

As per record of Philippine Statistics Authority [16] on the sectoral distribution of industries, the top five (5) industries in terms of number of Micro, Small and Medium Enterprises (MSME) in 2016 were: (1) Wholesale and Retail Trade (Merchandising); Repair of Motor Vehicles and Motorcycles (Servicing); (2) Accommodation and Food Service Activities; (3) Manufacturing; (4) Other Service Activities; and (5) Financial and Insurance Activities.

Furthermore, out of 171 merchandising businesses, 105 are small-size enterprises, and 66 are medium-sized enterprises. While, out of 120 servicing businesses, 78 are small-sized enterprises and 42 medium-sized enterprises. Lastly, out of 40 manufacturing businesses, 24 are small-size enterprises, and 16 are medium-sized enterprises.

Table 3. Profile of Small and Medium Enterprises, Isabela

\begin{tabular}{|c|c|c|}
\hline Profile & $\begin{array}{c}\text { Frequency } \\
\mathbf{N = 3 3 1}\end{array}$ & Percent \\
\hline Size of the Business & & \\
\hline Small & 207 & 62.54 \\
\hline Medium & 124 & 37.46 \\
\hline Type of Business & & \\
\hline Manufacturing & 40 & 12.09 \\
\hline Merchandising & 171 & 51.66 \\
\hline Servicing & 120 & 36.25 \\
\hline
\end{tabular}

\subsection{Overall Perception of Small and Medium Enterprises in Budgeting Practices, Isabela}

Table 4 presents the summary of budgeting practices, weighted mean and qualitative description. The table also displays that "linking budget development to strategy" has the highest mean of 4.02. Followed by "rational allocation of resources" with a mean of 4.01. On the other hand, the lowest means of 3.93 is "managers participation," "flexibility continuous improvement," and "reduction of complexity and use of information technology."

Moreover, the grand mean of 3.96 signifies that the respondents "agreed" on their overall view on budgeting practices. The data imply that the respondents have a good budgeting practice.

The following term was defined as used in the study of Mbothu [15]: (1) Manager's Participation. Worker's involvement in setting and developing organizational budgeting is a significant determinant of good budgeting. Staff participation in the budgeting process helps strengthen the perception among workers that organizational goals are fair. Therefore, the budget would be more relevant to them; (2) Linking Budget Development to Strategy. The budget expresses how resources will be allocated and what measures will be used to evaluate progress; budget development is more effective when linked to overall corporate strategy; (3) Rational Allocation of Resources. It analyses how scarce resources are distributed among producers and how scarce goods and services are apportioned among consumers;

Table 4. Overall Perception of Small and Medium Enterprises in Budgeting Practices, Isabela

\begin{tabular}{|c|c|c|}
\hline Items & Mean & $\begin{array}{c}\text { Qualitative } \\
\text { Description }\end{array}$ \\
\hline A. Managers Participation & 3.93 & Agree \\
\hline $\begin{array}{c}\text { B. Linking Budget } \\
\text { Development to Strategy }\end{array}$ & 4.02 & Agree \\
\hline $\begin{array}{c}\text { C. Rational Allocation of } \\
\text { Resources }\end{array}$ & 4.01 & Agree \\
\hline $\begin{array}{c}\text { D. Flexibility Continuous } \\
\text { Improvement }\end{array}$ & 3.93 & Agree \\
\hline $\begin{array}{c}\text { E. Reduction of Complexity } \\
\text { and Use of Information } \\
\text { Technology }\end{array}$ & 3.93 & Agree \\
\hline Grand Mean & 3.96 & Agree \\
\hline
\end{tabular}

(4) Flexibility Continuous Improvement. This term refers to the developing budgets that accommodate change ensures that the organization can respond to competitive threats or opportunities more quickly and with greater precision; and (5) Reduction of Complexity and Use of Information Technology. Best budgeting practices strive to reduce budget complexity and streamline budgeting procedures. The use of information technology and minimizing the amount of detail included in the reports used to develop budgets are other key steps technology has an important role in improving the efficiency of the budgeting process.

\subsection{Level of Profitability of Small and Medium Enterprises, Isabela}

As perceived from Table 5, the respondents have the highest mean of 3.53 on "return on investment" which denotes a high level of profitability. Also, a high level of profitability can also be seen in "return on assets" and "growth in sales/revenue" with a mean of 3.51 and 3.50, respectively. Then followed by an average level of profitability with a means of 3.49 on "profit margin" and return on equity." On the other hand, "economic value added" has the lowest mean of 3.47 which signifies an average level of profitability.

Furthermore, the grand mean of 3.50 denotes that the respondents' level of profitability is "high." The result implies that small and medium enterprises are profitable. Regarding income classification, Isabela is rated as the first-class province and considered as the top 10 richest provinces and the most progressive province in the 
Philippines and Region 2 [14].

Table 5. Level of Profitability of Small and Medium Enterprises, Isabela

\begin{tabular}{|c|c|c|}
\hline Items & Mean & $\begin{array}{c}\text { Qualitative } \\
\text { Description }\end{array}$ \\
\hline 1. Growth in Sales/Revenues & 3.50 & High \\
\hline 2. Profit Margin & 3.49 & Average \\
\hline 3. Return on Investment (ROI) & 3.53 & High \\
\hline 4. Return on Assets (ROA) & 3.51 & High \\
\hline 5. Return on Equity (ROE) & 3.49 & Average \\
\hline 6. Economic Value Added (EVA) & 3.47 & Average \\
\hline Grand Mean & 3.50 & High \\
\hline
\end{tabular}

\subsection{Comparison of the Overall Budgeting Practices Used as Perceived by the Respondents When Grouped According to the Size of the Business, Isabela}

As can be noticed from Table 6, there is no significant difference between the overall view of small and medium enterprises in "rational allocation of resources" with a significance level of $0.795(\mathrm{t}=-0.260)$, "flexibility of continuous improvement" with a significance level of $0.465(\mathrm{t}=-0.732)$ and "linking budget development to strategy" with a significance level of $0.252(t=-1.147)$. The result implies that regardless of the size of businesses, small-sized and medium-sized enterprises have the same (a) rational allocation of resources, (b) flexibility of continuous improvement and (c) linking budget development to strategy.

On the other hand, a significant difference exists in "reduction of complexity and use of information technology" with a significance level of $0.029(t=-2.192)$ and "managers participation" with a significance level of $0.022(\mathrm{t}=-2.294)$. The result implies that small and medium enterprises differ in budgeting practices used relative to (a) reduction of complexity and use of information technology and (b) managers participation.

The result agrees with Mayhew [17] that managers used an appropriate set of skills for their function, and the manner in which managers perform their duties is based on the company's size. One of the success factors for businesses is management skills, and small businesses are not an exception. The lack of management skills in small and medium enterprises places significant challenges in their development [18].

Likewise, the result suggests that medium-sized enterprises use information technology more extensively compared to small-sized enterprises. This difference in the size of business as to the use of information technology might be attributed to the situation that medium-sized enterprises have more assets compared to small-sized enterprises. According to Fuller-love [19] and Abor et al. [20], most SMEs suffer from the lack of access to appropriate technology. Moreover, a study conducted by Bouazza et al. [18], Premkumar [21] and Ghobakhloo et al. [22] revealed that financial restriction of SMEs regarding IT adoption is associated with the high cost of IT tools and infrastructure.

Moreover, there is no significant difference between the overall view of the small and medium enterprises on budgeting practices. The result suggests that the same budgeting process is practice regardless of the size of the business. The result is consistent with the findings of King et al. [23] that as to the size of the business, budgeting practice is not significant. He argued that regardless of the size of the business, budgeting practice is a need and companies can meet the costs related with implementing and operating one.

Table 6. Comparison of the Overall Budgeting Practices Used as Perceived by the Respondents When Grouped According to the Size of the Business, Isabela

\begin{tabular}{|c|c|c|c|c|c|}
\hline Items & Size of the Business & Mean & $\begin{array}{l}\text { Qualitative } \\
\text { Description } \\
\end{array}$ & $\mathrm{t}$ & Sig. (2-tailed) \\
\hline \multirow{2}{*}{ A. Managers Participation } & Small & 3.87 & Agree & \multirow{2}{*}{$-2.294^{*}$} & \multirow{2}{*}{.022} \\
\hline & Medium & 4.02 & Agree & & \\
\hline \multirow{2}{*}{$\begin{array}{l}\text { B. Linking Budget Development to } \\
\text { Strategy }\end{array}$} & Small & 3.99 & Agree & \multirow{2}{*}{$-1.147^{\mathrm{ns}}$} & \multirow{2}{*}{.252} \\
\hline & Medium & 4.06 & Agree & & \\
\hline \multirow{2}{*}{ C. Rational Allocation of Resources } & Small & 4.00 & Agree & \multirow{2}{*}{$-.260^{\mathrm{ns}}$} & \multirow{2}{*}{.795} \\
\hline & Medium & 4.02 & Agree & & \\
\hline \multirow{2}{*}{$\begin{array}{l}\text { D. Flexibility Continuous } \\
\text { Improvement }\end{array}$} & Small & 3.92 & Agree & \multirow{2}{*}{$-.732^{\mathrm{ns}}$} & \multirow{2}{*}{.465} \\
\hline & Medium & 3.97 & Agree & & \\
\hline \multirow{2}{*}{$\begin{array}{l}\text { E. Reduction of Complexity and Use } \\
\text { of Information Technology }\end{array}$} & Small & 3.87 & Agree & \multirow{2}{*}{$-2.192 *$} & \multirow{2}{*}{.029} \\
\hline & Medium & 4.03 & Agree & & \\
\hline \multirow{2}{*}{ Budgeting Practices } & Small & 3.93 & Agree & \multirow{2}{*}{$-1.793^{\mathrm{ns}}$} & \multirow{2}{*}{.074} \\
\hline & Medium & 4.02 & Agree & & \\
\hline
\end{tabular}

* Significant

ns Not Significant 


\subsection{Comparison of the Level of Profitability of the Respondents When Grouped According to the Size of the Business, Isabela}

As perceived from Table 7, growth in sales/revenue of small enterprises with a mean of 3.42 (description = average) and medium enterprises with a mean of 3.65 (description $=$ high) differs significantly with a significance level of 0.006. About profit margin, small enterprises with a mean of 3.40 (description = average) and medium enterprises with a mean of 3.65 differ significantly with a significance level of 0.002 . Regarding return on investment, small enterprises with a mean of 3.43 (description $=$ average) and medium enterprises with a mean of 3.72 differ significantly with a significance level of 0.000 . In relation to return on assets, small enterprises with a mean of 3.43 (description = average) and medium enterprises with a mean of 3.66 differ significantly with a significance level of 0.006 . About the return on equity, small enterprises with a mean of 3.40 (description $=$ average $)$ and medium enterprises with a mean of 3.65 differ significantly with a significance level of 0.001 . In connection to economic value-added, small enterprises with a mean of 3.41 (description = average) and medium enterprises with a mean of 3.56 differ significantly with a significance level of 0.042 . The result denotes that in all measures of profitability, medium enterprises exceeds the profit level of small enterprises.

Generally, the overall level of profitability of small enterprises with a mean of 3.41 (description = average) and medium enterprises with a mean of 3.65 (description $=$ high) signifies a significant difference exists between the sizes of businesses. Additionally, medium enterprises surpass the performance of small enterprises regarding profitability.

One of the main factors in determining the profitability of a firm is its size, and this is due to the concept known as economies of scale which can be found in the traditional neoclassical view of the firm. The analysis conducted by Pervan [24] for the 2002-2010 period showed that firm size has a weak significant positive effect on firm profitability. This is further concurred by the study conducted by Jonsson [25] and Mukhopadhyay et al. [26], which showed that bigger firms have higher profitability and growth advantage as compared to smaller firms.

\subsection{Overall Budgeting Practices Used as Perceived by the Respondents When Grouped According to the Type of the Business, Isabela}

As can be noticed from Table 8, there is no significant difference between the overall view of small and medium enterprises in "reduction of complexity and use of information technology" with a significance level of 0.352 ( F = 1.048), "flexibility continuous improvement" with a significance level of $0.321(\mathrm{~F}=1.140)$ and "rational allocation of resources" with a significance level of 0.258 $(\mathrm{F}=1.359)$. The result implies that regardless of the type of business, manufacturing, merchandising and servicing businesses have the same (a) reduction of complexity and use of information technology, (b) flexibility continuous improvement and (c) rational allocation of resources.

Table 7. Comparison of the Level of Profitability of the Respondents When Grouped According to the Size of the Business, Isabela

\begin{tabular}{|c|c|c|c|c|c|}
\hline Items & $\begin{array}{c}\text { Size of the } \\
\text { Business }\end{array}$ & Mean & $\begin{array}{l}\text { Qualitative } \\
\text { Description }\end{array}$ & $\mathrm{t}$ & Sig. (2-tailed) \\
\hline \multirow{2}{*}{ 1. Growth in Sales/Revenues } & Small & 3.42 & Average & \multirow{2}{*}{$-2.781 *$} & \multirow{2}{*}{.006} \\
\hline & Medium & 3.65 & High & & \\
\hline \multirow{2}{*}{ 2. Profit Margin } & Small & 3.40 & Average & \multirow{2}{*}{$-3.063 *$} & \multirow{2}{*}{.002} \\
\hline & Medium & 3.65 & High & & \\
\hline \multirow{2}{*}{ 3. Return on Investment (ROI) } & Small & 3.43 & Average & \multirow{2}{*}{$-3.609 *$} & \multirow{2}{*}{.000} \\
\hline & Medium & 3.72 & High & & \\
\hline \multirow{2}{*}{ 4. Return on Assets (ROA) } & Small & 3.43 & Average & \multirow{2}{*}{$-2.786^{*}$} & \multirow{2}{*}{.006} \\
\hline & Medium & 3.66 & High & & \\
\hline \multirow{2}{*}{ 5. Return on Equity (ROE) } & Small & 3.40 & Average & \multirow{2}{*}{$-3.292 *$} & \multirow{2}{*}{.001} \\
\hline & Medium & 3.65 & High & & \\
\hline \multirow{2}{*}{ 6. Economic Value Added (EVA) } & Small & 3.41 & Average & \multirow{2}{*}{$-2.040^{*}$} & \multirow{2}{*}{.042} \\
\hline & Medium & 3.56 & High & & \\
\hline \multirow{2}{*}{ Level of Profitability } & Small & 3.41 & Average & \multirow{2}{*}{$-3.237 *$} & \multirow{2}{*}{.001} \\
\hline & Medium & 3.65 & High & & \\
\hline
\end{tabular}

* Significant ns Not Significant 
On the other hand, a significant difference exists regarding "managers participation" with a significance level of 0.038 ( $\mathrm{F}=3.309)$ and "linking budget development to strategy" with a significance level of $0.015(\mathrm{~F}=4.282)$. Manufacturing with a mean of 3.71, merchandising with a mean of 3.96 and servicing with a mean of 3.95 differs significantly about managers participation. Additionally, manufacturing with a mean of 3.79 , merchandising with a mean of 4.07 and servicing with a mean of 4.03 differs significantly regarding linking budget development to strategy.

Furthermore, post hoc analysis of managers participation exhibited a significant difference between the manufacturing business and merchandising business with a significance level of 0.032 . The result deduces that the manufacturing business and merchandising business differ significantly in the budgeting process regarding managers participation. The result may be attributable to the fact that manufacturing firms are more complex organizations than merchandising firms [27] and therefore require more managers participation.

Likewise, post hoc analysis on the linked between budget development and strategic plan exhibited a significant difference between manufacturing business and merchandising business with a significance level of
0.010; and between manufacturing business and service business with a significance level of 0.044 . The result infers that manufacturing business differs with merchandising and servicing business in the budgeting process as to linking budget development to strategy. When overall corporate strategy is linked with budget development, then it will be more effective because the budget expresses how the resources will be allocated and what measure will be used to assess progress [28]. Yet, linking budget development to strategy is far more complicated for a manufacturing business, than merchandising and servicing business.

Moreover, there is no significant difference between the overall view of the different types of business on budgeting practices. The result concludes that the same budgeting process is being practiced regardless of the type of business. This is because budgeting practices are an integral part of running a business and therefore the same is being practiced irrespective of the type of business. However, the result is in contrast to Stice \& Stice [29] that the budgeting process of merchandising companies who buy products is less complicated compared to manufacturing companies who make products.

Table 8. Comparison of the Overall Budgeting Practices Used as Perceived by the Respondents When Grouped According to the Type of the Business, Isabela

\begin{tabular}{|c|c|c|c|c|c|}
\hline Items & Type of Business & Mean & $\begin{array}{l}\text { Qualitative } \\
\text { Description }\end{array}$ & $\mathrm{F}$ & Sig. \\
\hline \multirow{3}{*}{ A. Managers Participation } & Manufacturing & 3.71 & Agree & \multirow{3}{*}{$3.309 *$} & \multirow{3}{*}{.038} \\
\hline & Merchandising & 3.96 & Agree & & \\
\hline & Servicing & 3.95 & Agree & & \\
\hline \multirow{3}{*}{$\begin{array}{l}\text { B. Linking Budget Development to } \\
\text { Strategy }\end{array}$} & Manufacturing & 3.79 & Agree & \multirow{3}{*}{$4.282^{*}$} & \multirow{3}{*}{.015} \\
\hline & Merchandising & 4.07 & Agree & & \\
\hline & Servicing & 4.03 & Agree & & \\
\hline \multirow{3}{*}{$\begin{array}{l}\text { C. Rational Allocation of } \\
\text { Resources }\end{array}$} & Manufacturing & 3.86 & Agree & \multirow{3}{*}{$1.359^{\mathrm{ns}}$} & \multirow{3}{*}{.258} \\
\hline & Merchandising & 4.01 & Agree & & \\
\hline & Servicing & 4.05 & Agree & & \\
\hline \multirow{3}{*}{$\begin{array}{l}\text { D. Flexibility Continuous } \\
\text { Improvement }\end{array}$} & Manufacturing & 3.80 & Agree & \multirow{3}{*}{$1.140^{\mathrm{ns}}$} & \multirow{3}{*}{.321} \\
\hline & Merchandising & 3.95 & Agree & & \\
\hline & Servicing & 3.96 & Agree & & \\
\hline \multirow{3}{*}{$\begin{array}{l}\text { F. Reduction of Complexity and } \\
\text { Use of Information Technology }\end{array}$} & Manufacturing & 3.80 & Agree & \multirow{3}{*}{$1.048^{\mathrm{ns}}$} & \multirow{3}{*}{.352} \\
\hline & Merchandising & 3.93 & Agree & & \\
\hline & Servicing & 3.97 & Agree & & \\
\hline \multirow{3}{*}{ Budgeting Practices } & Manufacturing & 3.79 & Agree & \multirow{3}{*}{$3.011^{\mathrm{ns}}$} & \multirow{3}{*}{.051} \\
\hline & Merchandising & 3.98 & Agree & & \\
\hline & Servicing & 3.99 & Agree & & \\
\hline
\end{tabular}

* Significant ns Not Significant 
Table 9. Comparison of the Level of Profitability of the Respondents When Grouped According to the Type of the Business, Isabela

\begin{tabular}{|c|c|c|c|c|c|}
\hline Items & Type of Business & Mean & Qualitative Description & $\mathrm{F}$ & Sig. \\
\hline \multirow{3}{*}{ 1. Growth in Sales/Revenues } & Manufacturing & 3.48 & Average & $.525^{\mathrm{ns}}$ & .592 \\
\hline & Merchandising & 3.47 & Average & & \\
\hline & Servicing & 3.56 & High & & \\
\hline \multirow{3}{*}{ 2. Profit Margin } & Manufacturing & 3.48 & Average & $.109^{\mathrm{ns}}$ & .896 \\
\hline & Merchandising & 3.48 & Average & & \\
\hline & Servicing & 3.52 & High & & \\
\hline \multirow{3}{*}{ 3. Return on Investment (ROI) } & Manufacturing & 3.50 & High & $.092^{\mathrm{ns}}$ & .912 \\
\hline & Merchandising & 3.55 & High & & \\
\hline & Servicing & 3.53 & High & & \\
\hline \multirow{3}{*}{ 4. Return on Assets (ROA) } & Manufacturing & 3.40 & Average & $.772^{\mathrm{ns}}$ & .463 \\
\hline & Merchandising & 3.56 & High & & \\
\hline & Servicing & 3.51 & High & & \\
\hline \multirow{3}{*}{ 5. Return on Equity (ROE) } & Manufacturing & 3.43 & Average & $.361^{\mathrm{ns}}$ & .697 \\
\hline & Merchandising & 3.52 & High & & \\
\hline & Servicing & 3.48 & Average & & \\
\hline \multirow{3}{*}{$\begin{array}{l}\text { 6. Economic Value Added } \\
\text { (EVA) }\end{array}$} & Manufacturing & 3.38 & Average & $.470^{\mathrm{ns}}$ & .625 \\
\hline & Merchandising & 3.49 & High & & \\
\hline & Servicing & 3.46 & Average & & \\
\hline \multirow{3}{*}{ Level of Profitability } & Manufacturing & 3.44 & Average & $.198^{\mathrm{ns}}$ & .821 \\
\hline & Merchandising & 3.51 & High & & \\
\hline & Servicing & 3.51 & High & & \\
\hline
\end{tabular}

* Significant ns Not Significant

\subsection{Comparison of the Level of Profitability of the Respondents When Grouped According to the Type of the Business, Isabela}

Table 9 reveals that there is no significant difference between the level of profitability of the respondents in "return on investment" with a significance level of 0.912 $(\mathrm{F}=0.092)$, "profit margin" with a significance level of $0.896(\mathrm{~F}=0.092)$, "return on equity" with a significance level of $0.697(\mathrm{~F}=0.361)$, "economic value added" with a significance level of $0.625(\mathrm{~F}=0.470)$, "growth in sales/revenue" with a significance level of $0.592(\mathrm{~F}=525)$ and "return on assets" with a significance level of 0.463 (F $=0.772$ ). The result implies that regardless of the type of business, manufacturing, merchandising and servicing businesses have the same (a) return on investment, (b) profit margin, (c) return on equity, (d) economic value-added, (e) growth in sales/revenue and (f) return on assets.

Furthermore, there is no significant difference between the level of profitability of the different types of business. The result concludes that manufacturing, merchandising and servicing businesses have a similar level of profitability.

The result may be attributable to the fact that the chosen respondents were the most progressive regarding income classification in Isabela [14].

\subsection{Correlation between Overall Budgeting Practices Used as Perceived by the Respondents and Level of Profitability, Isabela}

As shown from Table 10, profitability level of small and medium enterprises is significantly correlated with their budgeting practices relative to managers participation, linking budget development to strategy, rational allocation of resources, flexibility continuous improvement, and reduction of complexity and use of information technology. The result also denotes that good budgeting practices directly affect the level of profitability of the respondents. This means that the level of profitability of small and medium enterprises increases as they adopt good budgeting practices.

Hence, the result agrees with the study conducted by Yang [13]. A study by Yang [13] is intended to gain a deeper understanding of how budgeting affects the performance of small and medium enterprises. He revealed that there is a positive effect of budgetary participation on performance. Companies necessitate prudent budgeting to achieve efficient and economical use of its resources and labor to increase profitability [30].

The result is also consistent with the findings of Faith [12]. Faith [12] studied the budgeting process in business enterprises and performance measurement in small and medium enterprises and found out that more formal plan in budgeting promotes higher growth of sales revenues in small and medium enterprises, clear and difficult budget goals improve budgetary performance of organizations, more sophisticated procedures of budgeting result in lower profit growth of small and medium enterprises, more formal budget mechanism leads to higher growth of profit in the organizations and greater budgetary participation leads to better managerial performance.

Furthermore, the result agrees with the findings of 
Mohamed et al. [31] and Pimpong et al. [32] that there exists a moderate positive association between budgeting and companies' performance.

Table 10. Correlation between Overall Budgeting Practices Used as Perceived by the Respondents and Level of Profitability, Isabela

\begin{tabular}{|c|c|c|}
\hline \multirow{2}{*}{ Correlation } & \multicolumn{2}{|c|}{ Level of Profitability } \\
\cline { 2 - 3 } & $\begin{array}{c}\text { Pearson } \\
\text { Correlation }\end{array}$ & $\begin{array}{c}\text { Sig. } \\
(2-\text { tailed })\end{array}$ \\
\hline A. Managers Participation & $.425^{* *}$ & .000 \\
\hline $\begin{array}{c}\text { B. Linking Budget Development to } \\
\text { Strategy }\end{array}$ & $.399^{* *}$ & .000 \\
\hline C. Rational Allocation of Resources & $.382^{* *}$ & .000 \\
\hline D. Flexibility Continuous Improvement & $.328^{* *}$ & .000 \\
\hline $\begin{array}{c}\text { E. Reduction of Complexity and Use of } \\
\text { IT }\end{array}$ & $.515^{* *}$ & .000 \\
\hline Budgeting Practices & $.527^{* *}$ & .000 \\
\hline
\end{tabular}

** correlation significant at the 0.01 level

* correlation significant at 0.05 level

As presented from Table 11, regression analysis showed that Linking Budget Development to Strategy, Rational Allocation of Resources, Flexibility Continuous Improvement is a predictor of profitability with a significance level of $0.043,0.010$ and 0.002 , respectively. While Managers Participation was not a predictor of profitability and Reduction of Complexity and IT use was excluded as a variable. Nonetheless, budgeting practices predict the profitability of the respondents.

Table 11. Regression Analysis between Overall Budgeting Practices Used as Perceived by the Respondents and Level of Profitability, Isabela

\begin{tabular}{|c|c|c|}
\hline Regression & $\mathrm{t}$ & Sig. \\
\hline A. Managers Participation & $-1.202^{\mathrm{ns}}$ & .230 \\
\hline $\begin{array}{c}\text { B. Linking Budget } \\
\text { Development to Strategy }\end{array}$ & $-2.033^{*}$ & .043 \\
\hline $\begin{array}{c}\text { C. Rational Allocation of } \\
\text { Resources }\end{array}$ & $-2.589^{*}$ & .010 \\
\hline $\begin{array}{c}\text { D. Flexibility Continuous } \\
\text { Improvement }\end{array}$ & $-3.181^{*}$ & .002 \\
\hline Budgeting Practices & $5.840^{*}$ & .000 \\
\hline
\end{tabular}

Dependent Variable: Level of Profitability

* Significant ns Not Significant

\section{Conclusions}

In light of the findings, the following conclusions were drawn.

1. Small-sized enterprises dominate the industry. Furthermore, the merchandising business and servicing business dominate the industry.

2. The respondents have a good budgeting practice relative to (a) active participation of management in the budgeting process, (b) linking budget development and strategic plans, (c) rational allocation of resources during the budgeting process, (d) development of a budget that accommodates and responds to changes and (e) streamlining budgeting procedures and usage of information technology.

3. The respondents, small and medium enterprises, are profitable.

4. Managers participation in the budgeting practice is directly related to the size of the business. Managers of medium-sized enterprises have higher involvement in the budgeting process compared to small-sized enterprises. On the other hand, medium-sized enterprises adopt information technology more extensive compared to small-sized enterprises. Companies strive to reduce budget complexity, and in their effort to streamline budgeting, companies use information technology to automate budgeting and simplify workflow. Moreover, the same budgeting process is practice regardless of the size of the business.

5. Bigger firms have higher profitability as compared to small firms.

6. Managers of merchandising and servicing business, as compared to manufacturing business, participate more in the budgeting process and establishes a link between budget development and strategic goals. Moreover, the same budgeting process is practice regardless of the type of business.

7. Manufacturing. Merchandising and servicing business have a similar level of profitability.

8. The level of profitability of small and medium enterprises increases as they adopt good budgeting practices. 


\section{Appendix - Research Questionnaire}

\section{Budgeting Practices as Perceived by the Respondents}

\begin{tabular}{|c|c|}
\hline A. & Managers Participation \\
\hline 1 & Non-finance managers participate actively in the budgeting process? \\
\hline 2 & Managers responsibility, role and authority in the budgeting process is clearly defined? \\
\hline 3 & Do managers have the prerequisite skills and knowledge in budgeting? \\
\hline 4 & Does top management provide the necessary support? \\
\hline 5 & Are you satisfied with the current budgeting system? \\
\hline B. & Linking budget development to strategy \\
\hline 1 & Is the budgeting system linked with the strategic plan? \\
\hline 2 & Objectives of the budget are realistic and achievable? \\
\hline 3 & The long-term objective of budgeting is understandable and act toward achieving the goals? \\
\hline 4 & The strategy of your business considers uncertain and uncontrollable factors? \\
\hline 5 & Is a budget a vital tool in management in your business? \\
\hline C. & Rational allocation of resources \\
\hline 1 & Your business carries out costs and benefit analysis when allocating resources in the budgeting process? \\
\hline 2 & Are resources allocated rationally and realistically in your budgeting process? \\
\hline 3 & All factors are considered when allocating resources in the budgeting process? \\
\hline 4 & Is budgeting a prerequisite to achieving your business goals? \\
\hline D. & Flexibility continuous improvement \\
\hline 1 & There is a possibility of revising the budget if there are changes in structure or business environment? \\
\hline 2 & Does your business consider the external environment while budgeting? \\
\hline 3 & Does your business prepare a regular budget variance report? \\
\hline 4 & Does performance measure include non-financial indicators? \\
\hline E. & Reduction of complexity \& use of information technology \\
\hline 1 & Do you have computerized budgeting software? \\
\hline 2 & Information required for the budgeting process is readily available in your business? \\
\hline 3 & Is budgeting data kept under strict security? \\
\hline 4 & The budgeting process in your business is clearly understood? \\
\hline 5 & The budgeting process is completed within a reasonable period? \\
\hline 6 & Budgeting does not unnecessarily disrupt nominal operations in your business? \\
\hline
\end{tabular}

\section{Level of Profitability}

\begin{tabular}{|c|c|}
\hline 1 & Growth in Sales/Revenues \\
\hline 2 & Profit Margin \\
\hline 3 & Return on Investment (ROI) \\
\hline 4 & Return on Assets (ROA) \\
\hline 5 & Return on Equity (ROE) \\
\hline 6 & Economic Value Added (EVA) \\
\hline
\end{tabular}




\section{REFERENCES}

[1] Kimunguyi, S., Memba, F., \& Njeru, A. (2015). Effect of Budgetary Process on Financial Performance of Ngos in Heath Sector in Kenya. International Journal of Business and social science, 6(12), 163-172.

[2] Milove, H. (2008). Small business owners and long-term financial planning. Accounting Today, 22(16), 18-21.

[3] Idhayajothi, R., Latasri, D. O., Manjula, N., Banu, A. M., \& Malini, R. (2014). A Study on Financial Performance of Ashok Leyland Limited at Chennai. IOSR Journal of Business and Management, 16(6), 83-89.

[4] RUSSIA'S G20 PRESIDENCY, \& OECD. (2013). Advancing national strategies for financial education.

[5] Shilpa, R., \& Rakesh, H. M. (2013). Analysis of effective utilization of funds. International Journal of Business and Management Invention, 2(1), 42-46.

[6] Managerial Accounting. (n.d.). Online available: https://courses.lumenlearning.com/sac-managacct/chapter/i ntroduction-to-budgeting-and-budgeting-processes/

[7] Management accounting and budgeting. (2020, April 16). Online available: https://rozlahey.com.au/services/manage ment-accounting-and-budgeting/

[8] Kimani, R. N. (2014). The Effect of Budgetary Control on Effectiveness of Non-government Organizations in Kenya, School of Business, University of Nairobi.

[9] A Prajapati (2019). Objectives of budgetary control: 6 main objectives. Economics Discussion. Online available from https://www.economicsdiscussion.net/cost-accounting/obje ctives-of-budgetary-control/31915

[10] Lidia, T. G. (2014). Difficulties of the budgeting process and factors leading to the decision to implement this management tool. Procedia Economics and Finance, 15, 466-473.

[11] Principles of Budgetary Governance. Online available: https://www.oecd.org/gov/budgeting/principles-budgetarygovernance.htm

[12] Maritim, F. C. (2013). The effects of budgeting process on financial performance of commercial and manufacturing parastatals in Kenya, University of Nairobi.

[13] Yang, Q. (2010). The Impact of the Budgetting Process on Performance in Small and Medium-sized Firms in China.

[14] Inquirer PH (2014). Isabela, the Regional Trade and Industrial Center of North-Eastern Luzon. Online available from http://lifestyle.inquirer.net/174837/isabelauncovered/

[15] Mbothu, J.W. (2012). The relationship between the Adoption of Best Budgeting Practices and Profitability in Private Hospitals in Nairobi County. School of Business, University of Nairobi.

[16] Philippine Statistics Authority. Highlights of the 2016 List of Establishments (LE). Online available from http://rsso08.psa.gov.ph/article/highlights-2016-list-establis hments-le\#sthash.Mw95obve.dpbs
[17] Mayhew, R. (2018). How the Size of the Organization Influences the Work of the Managers. Online available from https://smallbusiness.chron.com/size-organization-influenc es-work-manager-11677.html

[18] Bouazza, A. B., Ardjouman, D., \& Abada, O. (2015). Establishing the factors affecting the growth of small and medium-sized enterprises in Algeria. American International journal of Social science, 4(2), 101-115.

[19] Fuller-Love, N. (2006). Management development in small firms. Int. J. Manag. Rev. 2006, 8, 175-190.

[20] Abor, J., \& Quartey, P. (2010). Issues in SME development in Ghana and South Africa. International research journal of finance and economics, 39(6), 215-228.

[21] Premkumar, G. (2003). A meta-analysis of research on information technology implementation in small business. J. Org. Comp. Elect.Com 2003, 13, 91-121.

[22] Ghobakhloo, M., Hong, T. S., Sabouri, M. S., \& Zulkifli, N (2012). Strategies for successful information technology adoption in small and medium-sized enterprises. Information, 3(1), 36-67.

[23] King, R., Clarkson, P. M., \& Wallace, S. (2010). Budgeting practices and performance in small healthcare businesses. Management Accounting Research, 21(1), 40-55.

[24] Pervan, M., \& Višić, J. (2012). Influence of firm size on its business success. Croatian Operational Research Review, $3(1), 213-223$

[25] Jonsson, B. (2007). Does the size matter? The relationship between size and profitability of Icelandic firms. Bifrost Journal of Social Science, 1, 43-55.

[26] Mukhopadhyay, A., \& AmirKhalkhali, S. (2010). Profitability performance and firm size-growth relationship. Journal of Business \& Economics Research (JBER), 8(9).

[27] Franklin, M., Graybeal, P., \& Cooper, D. Principles of accounting volume 2 - Managerial accounting. OpenStax, 2019.

[28] Andersen, A. Best practices: Developing budgets. Inc.com. Online available from https://www.inc.com/articles/2000/01/16379.html

[29] Stice, J. \& Stice, E.K. (2015). Budgeting for merchandising firms. Accounting Foundations: Budgeting. Online available from https://www.lynda.com/Business-Accounting-tutorial s/Budgeting-merchandising-firms/383051/421085-4.html

[30] Advameg, Inc. (2020). Budgeting - benefits, expenses. Reference for Business - Encyclopedia of Small Business, Business Biographies, Business Plans, and Encyclopedia of American Industries. Online available from https://www.referenceforbusiness.com/encyclopedia/Bre-C ap/Budgeting.html

[31] Mohamed, A. I., \& Ali, A. Y. S. (2013). Relationship between Budgeting and Performance of Remittance Companies in Somalia. Educational Research International, 2(1), 106-115.

[32] Pimpong, S., \& Laryea, H. (2016). Budgeting and its impact on financial performance: The case of non-Bank financial institutions in Ghana. International Journal of Academic Research and Reflection, 4(5), 12-22. 